Open Access

\title{
Tight junction structure, function, and assessment in the critically ill: a systematic review
}

David Vermette ${ }^{1}$, Pamela Hu${ }^{1}$, Michael F Canarie ${ }^{1}$, Melissa Funaro ${ }^{2}$, Janis Glover ${ }^{2}$ and Richard W Pierce ${ }^{1 *}$

\author{
* Correspondence: Richard.Pierce@ \\ yale.edu \\ ${ }^{1}$ Department of Pediatrics, Yale \\ University, 333 Cedar Street, PO Box \\ 208064, New Haven, CT 06520, USA \\ Full list of author information is \\ available at the end of the article
}

\begin{abstract}
Background: Epithelial and endothelial barrier integrity, essential for homeostasis, is maintained by cellular boarder structures known as tight junctions (TJs). In critical illness, TJs may become disrupted, resulting in barrier dysfunction manifesting as capillary leak, pulmonary edema, gut bacterial translocation, and multiple organ failure. We aim to provide a clinically focused overview of TJ structure and function and systematically review and analyze all studies assessing markers of endothelial and epithelial TJ breakdown correlated with clinical outcomes in critically ill humans.

Methods: We systematically searched MEDLINE, EMBASE, and PubMed. Additional articles were identified by targeted searches. We included studies that looked at the relationship between biomarkers of endothelial or epithelial TJ structure or function and critical illness. Results were qualitatively analyzed due to sample size and heterogeneity.
\end{abstract}

Results: A total of 5297 abstracts met search criteria, of which 150 articles met requirements for full text review. Of these, 30 studies met inclusion criteria. Fifteen of the 30 reports investigated proteins of endothelial tight junctions and 15 investigated epithelial TJ markers, exclusively in the gastrointestinal epithelium. No studies investigated TJ-derived proteins in primary cardiac or pulmonary pathology.

Conclusions: TJ integrity is essential for homeostasis. We identified multiple studies that indicate TJs are disrupted by critical illness. These studies highlight the significance of barrier disruption across many critical disease states and correlate TJ-associated markers to clinically relevant outcomes. Further study on the role of multiple tissuespecific claudins, particularly in the setting of respiratory or cardiac failure, may lead to diagnostic and therapeutic advances.

Systematic review registration: This systematic review is registered in the PROSPERO database: CRD42017074546.

Keywords: Tight junctions, Epithelial cells, Endothelial cells, Cellular permeability, Capillary leak, Critical care

\section{Background}

Tight junctions (TJs) are protein complexes that form the semi-permeable connections between cells lining corporeal compartments [1]. In endothelial and epithelial cell layers, TJs are responsible for the selective barriers that permit specialized organ function [2]. Epithelial TJs regulate alveolar air-fluid balance in the lungs, the

(c) The Author(s). 2018 Open Access This article is distributed under the terms of the Creative Commons Attribution 4.0 International License (http://creativecommons.org/licenses/by/4.0/), which permits unrestricted use, distribution, and reproduction in any medium, provided you give appropriate credit to the original author(s) and the source, provide a link to the Creative Commons license, and indicate if changes were made. 
production of appropriately concentrated urine in the kidney, as well as the absorption of nutrients and containment of bacteria throughout the gastrointestinal tract [3]. TJs in endothelia maintain intravascular volume and regulate the flux of fluid and solutes between blood vessels and organ parenchyma [4]. Endothelial and epithelial barrier dysfunction in the setting of critical illness can result in malabsorption of nutrients, translocation of gut bacteria, capillary leak, interstitial edema, tissue dysoxia, and organ failure.

Unlike other cell junctions, TJs are the structures that maintain high resistance barriers. In the setting of critical illness, generally defined as life-threatening organ failure, they may become actively dismantled [5], resulting in the capillary leak phenomenon that complicates patient management [6]. Regardless of the etiology of organ failure, many critical care practitioners believe there is likely a common pathway of active junctional disassembly resulting in capillary leak, worsening organ failure, and if not addressed, death [7]. The extent to which changes in TJ morphology, or levels of TJ-associated proteins in serum or urine, correlate to these pathophysiological processes and, more significantly, clinical outcomes remain poorly understood. In this paper, we first undertake a clinically oriented overview of TJ structure and function, followed by a systematic review of the clinical investigations studying the assessment of $\mathrm{TJ}$ breakdown in critically ill humans.

\section{General structure and function of tight junctions Tight junction components and distribution}

In the late nineteenth century, TJs were first identified as the physical barrier to dye diffusion at the apical surface of intestinal epithelium, dubbed the "terminal bar." By the 1950s, TJs were recognized as key components to the barriers of frog skin and other epithelial layers [8]. Since then, TJs have been established as the primary regulators of fluid and solutes flux, based on size and charge (termed permselectivity). Research in animal models has helped to define the contributions of specific TJ proteins to tissue permselectivity and their function in disease states through knockout or overexpression studies [9]. Recent work has elucidated their roles as signaling platforms that establish cell polarity, transmit signals into nuclei, and modulate gene expression [10]. TJs are also capable of transmitting signals into cell nuclei via recruitment of adapter proteins [11]. No longer viewed as simple terminal bars, TJs are now seen as complex "plaques" containing more than 40 proteins that mechanically link adjoining cells and regulate tension, permselectivity, as well as cell signaling and gene expression [12].

Although comprised of many constituents, there are three transmembrane proteins that are common to all TJs: claudins, MARVEL domain proteins, and junctional adhesion molecules (JAMs, Fig. 1) [1]. The claudin family consists of 26 members and regulates the permselectivity of specific barriers (discussed below). The MARVEL domain proteins, occludin and tricellulin, are tetra-membrane spanning proteins that regulate the recruitment of signaling complex proteins to TJs [13]. JAM-A, -B, and -C are similar to immunoglobulin-G and may play important roles in barrier formation and signaling to circulating cells (i.e., platelets via JAM-B or leukocytes via JAM-A or -C) [14].

Claudins are the main regulators of TJ permselectivity [15]. These proteins have four transmembrane passages producing two extracellular loops that may interact with 


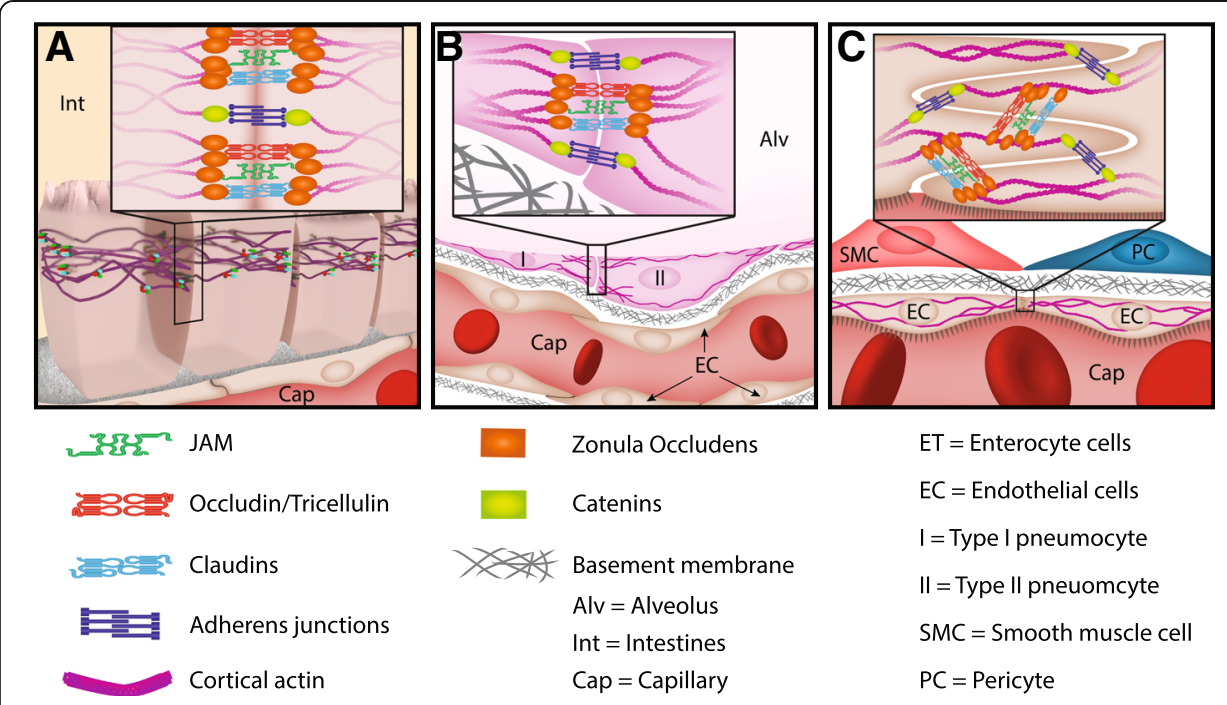

Fig. 1 Many different cell types utilize tight junction (TJ)-dependent barriers. TJs are comprised of occludin (also called tricellulin), junctional adhesion molecules (JAMs), and claudins. Variability in the claudin component (claudin-1 through -24) dictates the permselectivity of the barrier while JAMs may also vary (JAM-A, $-B$, or $-C)$, although their functional impact is less well understood. TJs are linked to the cytoskeleton through adapter proteins like zonula occludens (ZO-1, -2, and -3). a Columnar or cuboidal epithelia found in the upper airway, GI tract and parts of the nephron (proximal and distal tubules and collecting duct) form apical interlocking bands of tight junctions. b Squamous epithelia, such as in the lung, Bowman's capsule and thin segments of the nephron, have interspaced TJs without regard to cell polarity. c Simple squamous endothelia of blood vessels, blood-brain barrier, and lymphatic vessels have irregularly spaced TJs that vary greatly in number based on tissue and vascular segment specific microenvironments

claudins on the same or adjacent cells (homo-, hetero- and cis-, trans- interactions) [16]. This ability to mix and match interactions gives rise to the wide range of permselective barriers found in humans [17]. Claudin-5 promotes barrier function along with $-1,3,4,8,11,14$, and 19, while other claudin species reduce barrier function by forming ion pores like -2 and 10. Some claudin species have ambiguous or context-specific barrier properties $(-1,7,12$, and 15) [15].

The transmembrane components of claudin proteins link cells together while other proteins associate with the intracellular TJ plaque and facilitate intracellular signaling. Zonula occludens (ZO)-1, 2, and 3 (also known as TJ protein-1, 2, and 3) are the best studied examples [3]. ZO-1 is ubiquitously expressed in epithelial and endothelial cells and has multiple domains to facilitate cellular signaling. ZO-1 has three PDZ domains that bind claudins and JAMs, a GUK domain that binds occludin, a SH3 domain that binds the transcription factor ZONAB, and a carboxy-terminus that interacts with cytoskeletal F-actin [18]. These multiple protein interactions couple the extra- and intracellular signaling that allows the intricacy and plasticity of TJ function [10].

\section{Tight junction distribution in the epithelium}

Epithelial barriers are heterogeneous in their function and in the number and molecular composition of their TJs [19]. As measured by trans-epithelial electrical resistance, epithelial barrier function varies greatly among tissues, ranging from $>100,000 \Omega / \mathrm{cm}^{2}$ 
in the urinary bladder to $60 \Omega / \mathrm{cm}^{2}$ in the proximal jejunum [3]. This tissue-specific range of permeability is determined by the density of TJs as well as the specific claudin components [20]. Epithelial TJs exist predominately on the apical (luminal) aspect of cells and have much greater diversity of claudin expression (Fig. 1) [15]. Take for example, the nephron, where each segment has greatly different permselectivity and associated claudin expression (Table 1) [21].

Similarly, pulmonary epithelial cells express claudin species with regional diversity (Table 1). The pseudo-stratified columnar epithelium of the conducting airway (above generation 16) requires fluid flux for mucociliary transport. The squamous epithelium of the respiratory airways requires a tightly regulated thin layer of surfactant to maintain alveolar spaces for gas exchange [22]. At the alveolar level, there is greater variability of claudin expression in TJ formed by type 2 pneumocytes compared to type 1, reflecting their more variable functions [23].

Cell junctions in the gastrointestinal (GI) tract are perhaps the most complex, with variation along the length as well as within crypt-villi axes, reflecting the variable functions of the gut (Table 1) [24]. The GI barrier is comprised of intimately related endothelial and epithelial cells which depend on numerous, tract-specific claudins to selectively allow nutrient absorption while excluding bacteria [19]. Additional claudin species are likely expressed under special circumstances such as acute disease [25]. The spatial and temporal heterogeneity of claudin expression permits the range of permeability essential to GI function and adaptability. Unfortunately, this wide range of expression may limit the utility of these proteins as tissue-specific biomarkers.

Table 1 Predominate claudins expressed in selected tissues and tissue segments. Claudins-3 and -12 are especially concentrated in the cerebral endothelium

\begin{tabular}{ll}
\hline Tissue & Predominate claudin species \\
\hline Kidney & \\
Glomerulus & $-1,2,6$ \\
Proximal tubule & $-2,6,9,10,17$ \\
Thin limb & $-4,7,8,10$ \\
Thick limb & $-10,14,16,19$ \\
Collecting duct & $-3,4,7,8,10,18$ \\
Lungs & \\
Conducting airways & $-1,3,4,8$ \\
Respiratory airways & $-3,4,18$ \\
Gastrointestinal tract & \\
Stomach & $-2,3,4,10,13,18$ \\
Small intestine & $-3,4,5,18$ \\
Intestinal crypt & $-2,10,15$ \\
Intestinal villi & $-3,4,7,8,13,23$ \\
Colon & $-3,4,7,8$ \\
Endothelium & $-3,5,12$ \\
\hline
\end{tabular}


Tight junction distribution in the endothelium

Components of endothelial TJs are generally conserved throughout the endothelium. TJs are interspersed throughout areas of cell-cell overlap with little regard for cell polarity (Fig. 1). Regional permselectivity is established by varying the density and distribution of TJs between vascular segments [26]. The slightly permeable artery, arteriole, and large vein segments contain high numbers of regularly spaced TJs, whereas post-capillary venules typically have very few [27]. The permeability of the capillary segment is exquisitely organ specific, with highly permeable capillaries in the liver sinusoids that have fewer and more irregularly spaced TJs than less permeable capillaries such as those that line alveoli [28]. The least permeable capillaries are those that form the specialized blood-brain barrier [29].

The density and identity of claudins species dictate the permselectivity of organ-specific vascular segments. Claudin-5 is expressed by all endothelial cells. Claudins-1, 3, and 12 are also present in vascular endothelial TJs albeit at low levels. The blood-brain barrier is established by numerous TJs containing large amounts of claudins-3, 5, and 12 [29]. Occludin and zonulin (also known as prehaptoglobin-2) are expressed throughout the epithelium and endothelium while JAM-A and JAM-C are restricted to endothelium.

\section{Systematic review of the assessment of tight junction breakdown in critically ill humans}

Despite their importance, there has been little clinical research regarding how TJs respond to critical illness and how damage to specific corporeal barriers can be monitored [4]. Better assessments of TJ dysfunction in critical illness could help guide common therapies such as volume resuscitation, ventilator management, antibiotic therapy, or diuretic regimens and aid in the development of novel therapies that specifically target TJs. To define the state of the TJ-derived protein biomarker assessment in clinical research, we performed a systematic review and qualitative analysis of all investigations that assess TJ structure and function in critically ill humans.

\section{Methods}

We followed the Preferred Reporting Items for Systematic Reviews and Meta-Analyses. Our study protocol is registered in the PROSPERO database of systematic reviews, CRD42017074546 (Additional file 1: Table S1).

\section{Search strategy}

The authors conducted a systematic review, searching MEDLINE (Ovid MEDLINE 1946 to August Week 2 2017), Embase (Ovid Embase 1974 to 2017 August 21), and PubMed (through August 22, 2017) without language restriction. Searches in Embase and MEDLINE were limited using the human filter. Additional articles were identified by examining other systematic reviews, reference lists, bibliographies, and pre-identified websites such as research grant databases (NIH reporter), patent searches (USPTO search), conference abstracts (Web of Science), and publicly available internet searches (Google Scholar). Search strategy and terms, including both controlled vocabulary terms and free-text terms for the concepts of critical illness and tight junctions, are listed in Additional files 2: Tables S2 and Additional file 3: Table S3. 
On January 3, 2018, March 30, 2018, and June 11, 2018, updated searches were completed in MEDLINE, Embase, and PubMed. The search repeated the controlled vocabulary terms (Additional files 2: Tables S2 and Additional file 3: Table S3) and free text terms for the concept "critical illness" and then added terms for "tight junctions" and references were screened and selected as described.

\section{Study selection}

Two independent, blinded reviewers completed title, abstract, and full text screens of the results (Fig. 2). The senior author mediated consensus meetings to resolve discrepancies. Eligible studies include those assessing TJ structure or function in critically ill humans. Articles were screened for meeting the inclusion criteria: (1) observational case report, cohort, case control, or clinical trial studies; (2) studies involving critically ill human patients; and (3) studies assessing tight junction biomarkers or pathology (Additional files 2: Tables S2 and Additional file 3: Table S3). The determination of a patient as "critically ill" has some inherent variability, so we relied on the clinical impressions and determinations of the primary authors of each study. Studies

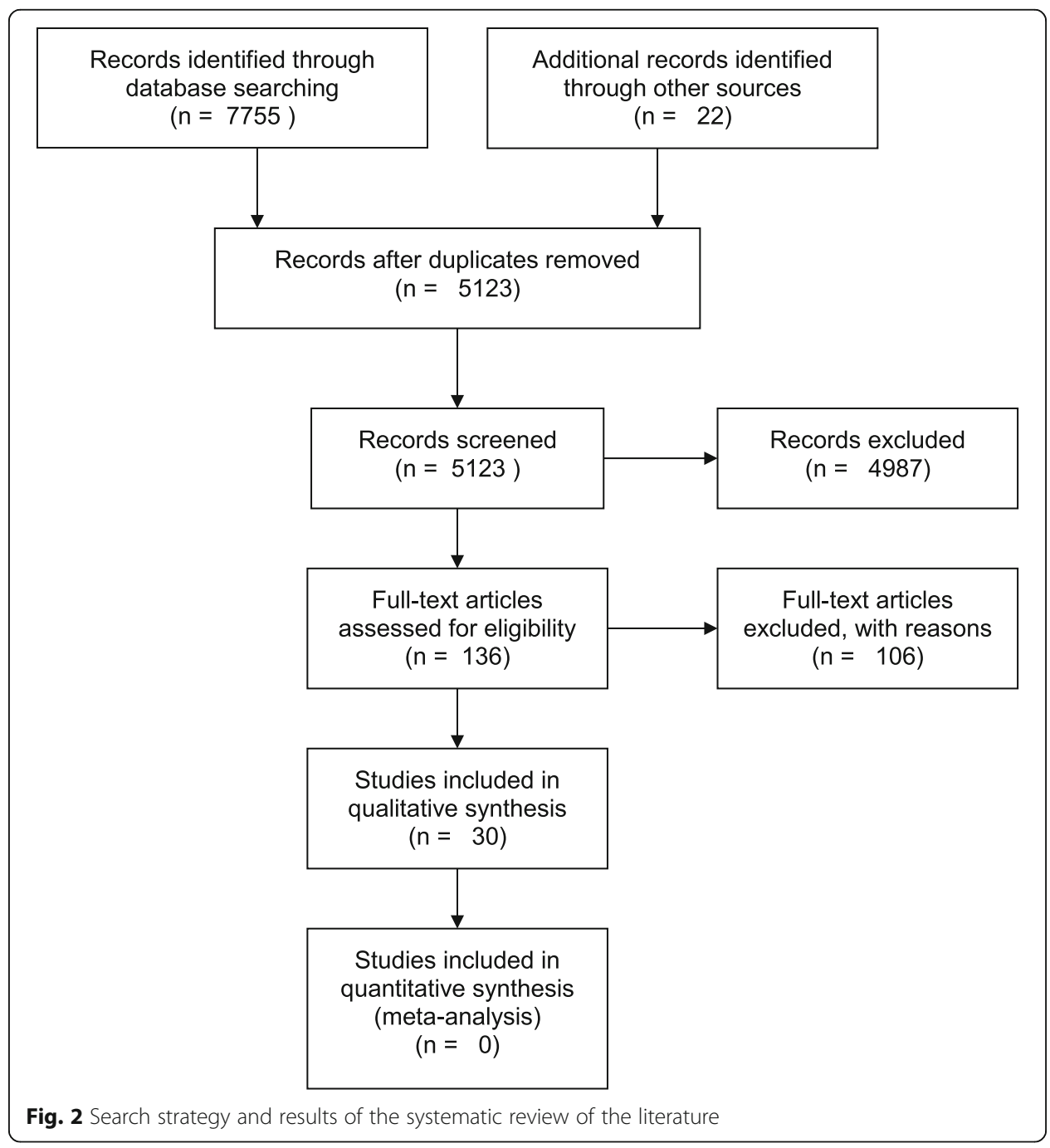


investigating animal or human cellular models (in vitro and ex vivo) as well as those that did not specifically assess TJ-derived protein components were excluded.

Studies examining barrier disruption due to cell apoptosis were excluded as this represents a different pathophysiologic process from the active TJ remodeling and cell junction disassembly of interest here [30-32]. Studies that evaluated the protein ZO-1 at intercalated discs of cardiomyocytes were also excluded since, although they contain protein ZO-1, these structures themselves are not TJs [33, 34].

\section{Assessment of the evidence and data abstraction}

All collected studies were reviewed using the Grades of Recommendation, Assessment, Development and Evaluation (GRADE) criteria from the Cochrane Review group [35]. A quantitative meta-analysis was not performed for several reasons. Relative estimates of effect could not be calculated for case series and studies that lacked control groups. Methodological heterogeneity, such as the type of tissue or fluid sampled, the timing of sampling relative to disease onset, and the wide range of analytical techniques employed (even between studies on the same molecule), further prohibited quantification of results. Therefore, all studies were qualitatively analyzed.

\section{Results}

A total of 5297 abstracts met search criteria for screening of which 150 articles satisfied the requirements for full text review. Of those, 30 studies were included that investigated biomarkers of epithelial (15 studies) and endothelial (15 studies) TJ structure or function in critically ill humans.

Overall, the quality of the identified evidence for using epithelial and endothelial biomarkers to predict outcomes is low. The main limitations were study design, as no randomized controlled trials were identified and only observational trials could be included. Moreover, these studies in general had low numbers of subjects and lacked control groups; 19 of the 30 studies identified included control patients while 18 of the 30 studies included involved 25 or less subjects. Only 2 identified studies included more than 100 subjects. Although trends were identified across studies, there was discordance in results for ZO-1 and claudin-2 in tissue samples between studies, likely due to different tissue and timing of collection relative to disease onset. Interpretation of pathology specimens was predominately qualitative, performed by individual authors, and primary data, such as complete histologic collections, could not be completely reviewed. The overall lack of standardization of tissue sample size, collection time, detection methods, and presentation of complete histologic datasets further downgraded the quality of the available evidence.

\section{Epithelial injury}

Fifteen studies looked at epithelial TJs, all focusing on TJ regulation in the GI tract during critical illness (Table 2). Of these, 13 were prospective observational and 2 were cross-sectional studies. Nine studies examined biopsy specimens without a consistent approach to the timing of biopsies relative to onset of illness or segment of bowel sampled. Despite this heterogeneity, these studies collectively demonstrate that TJs become disrupted in response to critical illness. In concordance with the histologic findings, 
Table 2 Summary of studies investigating markers of epithelial injury listed in descending chronological order

\begin{tabular}{|c|c|c|c|c|c|c|}
\hline Study & Study design & $\begin{array}{l}\text { Disease } \\
\text { process }\end{array}$ & $\begin{array}{l}\text { Method } \\
\text { of TJ } \\
\text { assessment }\end{array}$ & $\begin{array}{l}\text { \# of Pts } \\
\text { (controls) }\end{array}$ & $\begin{array}{l}\text { TJ } \\
\text { proteins } \\
\text { studied }\end{array}$ & Major findings \\
\hline $\begin{array}{l}\text { Amadi } \\
\text { et al. } 2017 \text { [36] }\end{array}$ & $\begin{array}{l}\text { Prospective } \\
\text { observational } \\
\text { study }\end{array}$ & $\begin{array}{l}\text { Severe acute } \\
\text { malnutrition }\end{array}$ & $\begin{array}{l}\text { Intestinal } \\
\text { biopsy; IHC }\end{array}$ & $34(0)$ & Claudin-4 & $\begin{array}{l}\text { Reduced claudin- } 4 \text { tissue } \\
\text { staining overall, with in } \\
\text { creased staining and more } \\
\text { disorganization at epithelial } \\
\text { breaks and villus tips }\end{array}$ \\
\hline $\begin{array}{l}\text { Bein et al. } \\
2017 \text { [71] }\end{array}$ & $\begin{array}{l}\text { Cross- } \\
\text { sectional } \\
\text { study }\end{array}$ & NEC & $\begin{array}{l}\text { RT-PCR; } \\
\text { IHC }\end{array}$ & $6(6)$ & $\begin{array}{l}\text { ZO-1, } \\
\text { occludin, } \\
\text { claudin-4, } \\
\text { cingulin }\end{array}$ & $\begin{array}{l}\text { Decreased expression of } \\
\text { occludin and ZO- } 1 \text { in the } \\
\text { jejunum and ileum of NEC } \\
\text { patients }\end{array}$ \\
\hline $\begin{array}{l}\text { Goswami } \\
\text { et al. 2017 [72] }\end{array}$ & $\begin{array}{l}\text { Prospective } \\
\text { observational } \\
\text { study }\end{array}$ & SAP & $\begin{array}{l}\text { Duodenal } \\
\text { biopsy; } \\
\text { IHC; RT- } \\
\text { PCR; EM }\end{array}$ & $26(10)$ & $\begin{array}{l}\text { Claudin- } \\
2,-4\end{array}$ & $\begin{array}{l}\text { Decreased claudin-4 in } \\
\text { villi and crypts; Increased } \\
\text { expression of claudin-2 and } \\
\text { disruption of TJ by EM } \\
\text { in SAP }\end{array}$ \\
\hline $\begin{array}{l}\text { Greis et al. } \\
2017 \text { [40] }\end{array}$ & $\begin{array}{l}\text { Prospective } \\
\text { observational } \\
\text { study }\end{array}$ & $\begin{array}{l}\text { Intestinal } \\
\text { dysfunction in } \\
\text { mechanically } \\
\text { ventilated } \\
\text { patients }\end{array}$ & $\begin{array}{l}\text { Serum } \\
\text { ELISA }\end{array}$ & $50(0)$ & Zonulin & $\begin{array}{l}\text { Increased serum zonulin ( } 2.5 \\
10.4 \mathrm{ng} / \mathrm{mL} \text { ) associated with } \\
\text { delayed gastric emptying }\end{array}$ \\
\hline $\begin{array}{l}\text { Habes } \\
\text { et al. } 2017 \text { [38] }\end{array}$ & $\begin{array}{l}\text { Cross- } \\
\text { sectional } \\
\text { study }\end{array}$ & $\begin{array}{l}\text { Intestinal injury } \\
\text { after cardiac } \\
\text { surgery }\end{array}$ & $\begin{array}{l}\text { Urine } \\
\text { ELISA }\end{array}$ & $37(0)$ & Claudin-3 & $\begin{array}{l}\text { Urinary claudin-3 ( } 0 \text { to } \\
0.23 \mathrm{ng} / \mathrm{mL} \text { ) increased at } \\
\text { onset of surgery, peaked } \\
\text { at end of surgery and } \\
\text { normalized over several days }\end{array}$ \\
\hline $\begin{array}{l}\text { Sipola et al. } \\
2017 \text { [41] }\end{array}$ & $\begin{array}{l}\text { Prospective } \\
\text { observational } \\
\text { study }\end{array}$ & $\begin{array}{l}\text { Emergent } \\
\text { colectomy }\end{array}$ & $\begin{array}{l}\text { Colectomy } \\
\text { samples; } \\
\text { IHC }\end{array}$ & $38(28)$ & $\begin{array}{l}\text { Claudin- } \\
1,-2 ; \\
\text { occludin }\end{array}$ & $\begin{array}{l}\text { Decreased claudin-1 tissue } \\
\text { staining in the damaged } \\
\text { colon of critically ill patients. } \\
\text { No significant changes seen } \\
\text { with claudin-2 or occludin } \\
\text { expression }\end{array}$ \\
\hline $\begin{array}{l}\text { Tarko et al. } \\
2017 \text { [45] }\end{array}$ & $\begin{array}{l}\text { Prospective } \\
\text { observational } \\
\text { study }\end{array}$ & $\begin{array}{l}\text { NEC, rotavirus } \\
\text { and } \\
\text { gastroschisis }\end{array}$ & $\begin{array}{l}\text { Serum } \\
\text { ELISA }\end{array}$ & $67(14)$ & Zonulin & $\begin{array}{l}\text { Increased serum zonulin } \\
\text { ( } 2 \text { to } 43 \mathrm{ng} / \mathrm{mL} \text { ) levels in } \\
\text { patients with rotavirus and } \\
\text { gastroschisis }\end{array}$ \\
\hline $\begin{array}{l}\text { Wen et al. } \\
2017 \text { [47] }\end{array}$ & $\begin{array}{l}\text { Prospective } \\
\text { observational } \\
\text { study }\end{array}$ & SAP & $\begin{array}{l}\text { Colonic } \\
\text { biopsy; IF; } \\
\text { WB }\end{array}$ & $31(8)$ & $\begin{array}{l}\text { Claudin-2; } \\
\text { occludin; } \\
\text { ZO-1 }\end{array}$ & $\begin{array}{l}\text { Increased claudin-2 and } \\
\text { decreased occludin and } \\
\text { ZO-1 tissue staining } \\
\text { associated with bacterial } \\
\text { translocation }\end{array}$ \\
\hline $\begin{array}{l}\text { Liew et al. } \\
2016 \text { [42] }\end{array}$ & $\begin{array}{l}\text { Prospective } \\
\text { observational } \\
\text { study }\end{array}$ & $\begin{array}{l}\text { Mechanically } \\
\text { ventilated } \\
\text { adults }\end{array}$ & $\begin{array}{l}\text { Duodenal } \\
\text { biopsy, EM }\end{array}$ & $12(15)$ & $\begin{array}{l}\text { Not } \\
\text { specified }\end{array}$ & $\begin{array}{l}\text { No abnormalities of TJ } \\
\text { ultrastructure were } \\
\text { appreciated in the duodenal } \\
\text { samples of patients in either } \\
\text { the critically ill group or } \\
\text { control group }\end{array}$ \\
\hline $\begin{array}{l}\text { Sonika } \\
\text { et al. } 2016 \\
\text { [48] }\end{array}$ & $\begin{array}{l}\text { Prospective } \\
\text { observational } \\
\text { study }\end{array}$ & SAP & $\begin{array}{l}\text { Duodenal } \\
\text { biopsy; IHC }\end{array}$ & $20(20)$ & $\begin{array}{l}\text { Claudin- } \\
2,-4\end{array}$ & $\begin{array}{l}\text { Significantly decreased tissue } \\
\text { staining of claudin-4 in duo } \\
\text { denal villi and crypts but not } \\
\text { significantly decreased at } \\
\text { intercellular junctions. } \\
\text { Claudin-2 had no statistically } \\
\text { significant changes }\end{array}$ \\
\hline $\begin{array}{l}\text { Blackwood } \\
\text { et al. } 2015 \\
\text { [43] }\end{array}$ & $\begin{array}{l}\text { Prospective } \\
\text { observational } \\
\text { study }\end{array}$ & NEC & $\begin{array}{l}\text { Intestinal } \\
\text { biopsy IF; } \\
\text { urine WB }\end{array}$ & $3(3)$ & Claudin-2 & $\begin{array}{l}\text { Reduced claudin-2 tissue } \\
\text { staining with an increase in } \\
\text { urinary claudin-2 }\end{array}$ \\
\hline $\begin{array}{l}\text { Typpo } \\
\text { et al. } 2015 \\
\text { [39] }\end{array}$ & $\begin{array}{l}\text { Prospective } \\
\text { observational } \\
\text { study }\end{array}$ & $\begin{array}{l}\text { Intestinal } \\
\text { dysfunction } \\
\text { after CPB }\end{array}$ & $\begin{array}{l}\text { Serum } \\
\text { ELISA }\end{array}$ & $20(0)$ & Claudin-3 & $\begin{array}{l}\text { Increased plasma claudin-3 } \\
\text { (0 to } 18 \mathrm{ng} / \mathrm{mL} \text { ) levels more } \\
\text { than } 120 \mathrm{~h} \text { after CPB were } \\
\text { associated with fluid overload }\end{array}$ \\
\hline
\end{tabular}


Table 2 Summary of studies investigating markers of epithelial injury listed in descending chronological order (Continued)

\begin{tabular}{|c|c|c|c|c|c|c|}
\hline Study & Study design & $\begin{array}{l}\text { Disease } \\
\text { process }\end{array}$ & $\begin{array}{l}\text { Method } \\
\text { of TJ } \\
\text { assessment }\end{array}$ & $\begin{array}{l}\text { \# of Pts } \\
\text { (controls) }\end{array}$ & $\begin{array}{l}\text { TJ } \\
\text { proteins } \\
\text { studied }\end{array}$ & Major findings \\
\hline & & & & & & $\begin{array}{l}\text { feeding intolerance and } \\
\text { duration of antibiotic } \\
\text { treatment }\end{array}$ \\
\hline $\begin{array}{l}\text { De Plaen et al. } \\
2012 \text { [46] }\end{array}$ & $\begin{array}{l}\text { Prospective } \\
\text { observational } \\
\text { study }\end{array}$ & NEC & $\begin{array}{l}\text { Colonic } \\
\text { and small } \\
\text { intestine } \\
\text { biopsy; IHC }\end{array}$ & $20(20)$ & $\begin{array}{l}\text { Claudin- } \\
\text { 2,-4; } \\
\text { occludin; } \\
\text { ZO-1 }\end{array}$ & $\begin{array}{l}\text { Increased tissue staining of } \\
\text { claudin-2 but not of } \\
\text { claudin-4, occludin, or ZO-1 }\end{array}$ \\
\hline $\begin{array}{l}\text { Thuijls et al. } \\
2010 \text { [44] }\end{array}$ & $\begin{array}{l}\text { Prospective } \\
\text { observational } \\
\text { study }\end{array}$ & NEC & Urine WB & $14(21)$ & Claudin-3 & $\begin{array}{l}\text { Increased urinary claudin-3 } \\
\text { in patients who developed } \\
\text { NEC }\end{array}$ \\
\hline $\begin{array}{l}\text { Derikx et al. } \\
2008 \text { [37] }\end{array}$ & $\begin{array}{l}\text { Prospective } \\
\text { observational } \\
\text { study }\end{array}$ & $\begin{array}{l}\text { Intestinal injury } \\
\text { after non-Gl } \\
\text { surgery in } \\
\text { children }\end{array}$ & Urine WB & $20(0)$ & Claudin-3 & $\begin{array}{l}\text { Increased urine claudin-3 } \\
\text { associated with onset of } \\
\text { surgery and rapid return } \\
\text { to baseline levels }\end{array}$ \\
\hline
\end{tabular}

IHC immunohistochemistry, IF immunofluorescence, EM electron microscopy, WB Western blot, ELISA enzyme-linked immunosorbent assay, NEC necrotizing enterocolitis, SAP severe acute pancreatitis, CPB cardiopulmonary bypass, IP intestinal permeability, CSF cerebral spinal fluid, $G$ g gastrointestinal, $R T-P C R$ reverse transcription polymerase chain reaction, ZO-1 zonula occludens, NR not reported

multiple markers of TJ disruption were detected in blood or urine. However, these studies must be carefully interpreted within their individual clinical contexts as zonulin is widely expressed in most cell types while claudins-3 and -4 may be more specific for EC injury. Notably, no studies specifically evaluated TJ proteins enriched in pulmonary or renal epithelium. Seven studies investigated GI-derived TJ markers, in the settings of severe malnutrition [36], non-GI surgery [37], congenital heart surgery requiring cardiopulmonary bypass [38, 39], and general critical illness [40-42]. All together, these studies found disrupted TJs as assessed by histology or electron microscopy. Combining a variety of investigative methods, including histology or electron microscopy, these studies collectively indicate that TJs in the GI tract are disrupted in critical illness. Decreased serum levels of claudin-4 were found in malnutrition states [36]. Decreased claudin-1, but not claudin-2 or occludin, was detected after emergent colectomy [41]. Urinary and plasma claudin-3 concentrations increased after major surgery and correlated with clinical parameters [37-39]. Mechanically ventilated patients had increased levels of serum zonulin associated with decreased gastric motility [40] and, among those without overt GI pathology, had generally intact TJ ultrastructure [42].

Five studies investigated TJs in infants with necrotizing enterocolitis (NEC). Urinary claudin-2 [43] and -3 [44] and plasma zonulin [45] are elevated in this setting and correlate temporally with episodes of NEC. Tissue levels of claudin-2 are also altered in NEC, with increased staining in the colon [46] and decreased staining in the intestine [43]. Expression of occludin and ZO-1 in the jejunum and ileum of patients with NEC was found to be decreased (31).

Lastly, three studies investigated TJ biomarkers in colonic tissue from patients with severe acute pancreatitis (SAP). These studies demonstrated decreased expression of ZO-1, occludin, and claudin-4 in either duodenal or colonic tissue [47-49]. The magnitude of decreased ZO-1 expression correlated with the degree of bacterial translocation [47, 49]. 


\section{Endothelial injury}

Fifteen studies, of which 9 were prospective observational, 5 were cross sectional, and 1 was a case report, evaluated endothelial TJ proteins in the setting of neurologic injury, sepsis, and trauma (Table 3). There were three studies on ischemic stroke [50-52], and one study on each of the following: intracranial hemorrhage [53], cerebral edema [54], kernicterus [55], cerebral malaria [52], and fatal heat stroke [56], two studies on trauma $[57,58]$. There were an additional five studies on sepsis [59-63]. However, claudin-5 is restricted to EC, while ZO-1, occludin, JAM-A, vinculin, and zonulin are expressed in other cells, and elevated levels may not reflect $\mathrm{TJ}$ breakdown. Therefore, interpretation of studies of these proteins must take into account the specific clinical context and be correlated with other cellular injury.

The largest study identified included 458 patients and found that the serum levels of claudin-5, occludin, and the claudin-5-to-ZO-1 ratio were significantly increased in patients with hemorrhagic conversion of ischemic stroke [51]. These markers demonstrated high negative predictive value in this setting as well, specifically occludin (95.5\%), claudin 5 (94.5\%), occludin-to-claudin-5 ratio (88.9\%), ZO-1 (94.3\%), and claudin-5-to-ZO1-ratio (95.9\%). In other studies of stroke [52], JAM-A, ZO-1, and claudin- 5 were found not to correlate with blood-brain barrier breakdown in the acute phase; however, a decrease in claudin-5 levels may indicate improved barrier function by 10 days. In the largest study identified [51], increased serum occludin and elevated claudin-5 to ZO-1 ratio was associated with worse hemorrhage and neuronal injury (as measured by S100B levels). In intracranial hemorrhage, claudin-5, occludin, and ZO-1 sampled from cerebrospinal fluid may be more specific than serum markers [53].

Changes in vascular TJ architecture have been associated with cerebral edema. A study looking at electron microscopy of autopsy specimens demonstrated TJ disruption in cerebral edema due to hemorrhagic congenital malformations, brain tumors, or trauma [54]. Claudin-5 is increased in metabolic encephalopathies such as kernicterus [55]. In the setting of infection such as cerebral malaria, ZO-1, occludin, and vinculin are downregulated [64]. Lastly, in the setting of fatal heat stroke, serum claudin-5, ZO-1, and occludin levels are unchanged [56]. No studies have investigated blood-brain barrier-specific claudins in critical injury.

Systemic endothelial disruption in the setting of trauma was investigated in two studies. First, in polytrauma patients, JAM-A is significantly elevated within $4 \mathrm{~h}$ and correlated with clinical severity scores and outcomes [58]. Second, in patients with trauma-induced hemorrhagic shock, claudin-5 is elevated and correlated with serum lactate, indicating that endothelial damage may correlate with systemic oxygen delivery [57].

Five studies have investigated TJs in sepsis, with three investigating serum biomarkers and two focusing on renal biopsies in sepsis-associated kidney failure. Collectively, these studies demonstrate that serum levels of ZO-1, occludin, zonulin, and claudin-5 are elevated in sepsis $[59,61,63]$. ZO-1 may be more predictive of multiple organ dysfunction and mortality than claudin-5 or procalcitonin in septic patients presenting to the emergency department [61]. Likewise, in the setting of Dengue fever, claudin-5 levels correlate with the degree of clinical plasma leakage [60]. In sepsis-induced kidney injury, claudin-5 may be increased and ZO-1 decreased in endothelial cells of biopsy specimens [59]. However, no kidney-specific epithelial claudins were assessed. 
Table 3 Summary of studies investigating markers of endothelial injury listed in descending chronological order

\begin{tabular}{|c|c|c|c|c|c|c|}
\hline Study & Study design & $\begin{array}{l}\text { Disease } \\
\text { process }\end{array}$ & $\begin{array}{l}\text { Method } \\
\text { of TJ } \\
\text { assessment }\end{array}$ & $\begin{array}{l}\text { \# of Pts } \\
\text { (controls) }\end{array}$ & $\begin{array}{l}\text { TJ } \\
\text { proteins } \\
\text { studied }\end{array}$ & Major findings \\
\hline $\begin{array}{l}\text { Aslan et al. } \\
2017 \text { [59] }\end{array}$ & $\begin{array}{l}\text { Cross- } \\
\text { sectional } \\
\text { study }\end{array}$ & Severe sepsis & $\begin{array}{l}\text { Post- } \\
\text { mortem } \\
\text { kidney } \\
\text { biopsy; RT- } \\
\text { PCR }\end{array}$ & $19(12)$ & $\begin{array}{l}\text { Claudin-5; } \\
\text { occludin }\end{array}$ & $\begin{array}{l}\text { Increased claudin-5 mRNA } \\
\text { expression associated with } \\
\text { sepsis and no significant } \\
\text { difference in occludin mRNA } \\
\text { expression }\end{array}$ \\
\hline $\begin{array}{l}\text { Du et al. } \\
2017 \text { [56] }\end{array}$ & $\begin{array}{l}\text { Cross- } \\
\text { sectional } \\
\text { study }\end{array}$ & $\begin{array}{l}\text { Fatal heat } \\
\text { stroke }\end{array}$ & $\begin{array}{l}\text { Post- } \\
\text { mortem } \\
\text { brain } \\
\text { biopsy; } \\
\text { IHC; RT- } \\
\text { PCR }\end{array}$ & $23(23)$ & $\begin{array}{l}\text { Claudin-5; } \\
\text { occludin; } \\
\text { ZO-1 }\end{array}$ & $\begin{array}{l}\text { No significant difference in } \\
\text { staining of claudin- } 5 \text {, } \\
\text { occludin or ZO- } 1 \text { between } \\
\text { heat stroke and control group }\end{array}$ \\
\hline $\begin{array}{l}\text { Halbgebauer } \\
\text { et al. } \\
2017 \text { [57] }\end{array}$ & $\begin{array}{l}\text { Prospective } \\
\text { observational } \\
\text { study }\end{array}$ & Polytrauma & $\begin{array}{l}\text { Serum } \\
\text { ELISA }\end{array}$ & $30(0)$ & Claudin-5 & $\begin{array}{l}\text { Increased serum claudin- } 5 \\
\text { ( } 20 \text { to } 400 \mathrm{ng} / \mathrm{mL} \text { ) levels } \\
\text { associated with hemorrhagic } \\
\text { shock, serum lactate and } \\
\text { need for transfusion }\end{array}$ \\
\hline $\begin{array}{l}\text { Ji et al. } \\
2017 \text { [50] }\end{array}$ & $\begin{array}{l}\text { Randomized } \\
\text { prospective } \\
\text { study }\end{array}$ & $\begin{array}{l}\text { Ischemic } \\
\text { stroke }\end{array}$ & $\begin{array}{l}\text { Serum } \\
\text { ELISA }\end{array}$ & $16(14)$ & $\begin{array}{l}\text { Claudin-5; } \\
\text { ZO-1 }\end{array}$ & $\begin{array}{l}\text { No difference in claudin- } 5 \text { or } \\
\text { ZO- } 1 \text { (NR) between treatment } \\
\text { groups in the acute phase, } \\
\text { but decreased serum claudin- } \\
5 \text { ( } 338 \text { versus } 408 \mathrm{ng} / \mathrm{mL} \text { ) in } \\
\text { the treatment group after } \\
10 \text { days }\end{array}$ \\
\hline $\begin{array}{l}\text { Suwarto } \\
\text { et al. } \\
2017 \text { [60] }\end{array}$ & $\begin{array}{l}\text { Prospective } \\
\text { observational } \\
\text { study }\end{array}$ & $\begin{array}{l}\text { Dengue } \\
\text { fever }\end{array}$ & $\begin{array}{l}\text { Serum } \\
\text { ELISA }\end{array}$ & $103(0)$ & Claudin-5 & $\begin{array}{l}\text { Significantly increased serum } \\
\text { claudin-5 ( } 17.4 \text { to } 81.1 \mathrm{ng} / \\
\mathrm{mL} \text { ) levels associated with } \\
\text { dengue with severe plasma } \\
\text { leakage as compared to } \\
\text { dengue fever and dengue } \\
\text { hemorrhagic fever }\end{array}$ \\
\hline $\begin{array}{l}\text { Zhao et al. } \\
2016 \text { [61] }\end{array}$ & $\begin{array}{l}\text { Cross- } \\
\text { sectional } \\
\text { study }\end{array}$ & Sepsis & $\begin{array}{l}\text { Serum } \\
\text { ELISA }\end{array}$ & $51(0)$ & $\begin{array}{l}\text { Claudin-5; } \\
\text { occludin; } \\
\text { ZO-1 }\end{array}$ & $\begin{array}{l}\text { Increased serum occludin } \\
\text { ( } 285 \text { versus } 607 \mathrm{pg} / \mathrm{mL} \text { ) and } \\
\text { ZO-1 ( } 54 \text { versus } 735 \mathrm{pg} / \mathrm{mL} \text { ) } \\
\text { in severe sepsis and septic } \\
\text { shock and negatively } \\
\text { associated with survival. } \\
\text { Increased serum ZO-1, but } \\
\text { not occludin, associated } \\
\text { with multiple organ } \\
\text { dysfunction syndrome. No } \\
\text { significant differences found } \\
\text { in claudin-5 levels (281 } \\
\text { versus } 263 \mathrm{pg} / \mathrm{mL} \text { ) between } \\
\text { survivors and non-survivors } \\
\text { and MODS and non-MODS } \\
\text { groups }\end{array}$ \\
\hline $\begin{array}{l}\text { Denk et al. } \\
2015 \text { [58] }\end{array}$ & $\begin{array}{l}\text { Prospective } \\
\text { observational } \\
\text { study }\end{array}$ & Polytrauma & $\begin{array}{l}\text { Serum } \\
\text { ELISA }\end{array}$ & $8(10)$ & JAM-A & $\begin{array}{l}\text { Increased serum JAM-A (4 to } \\
10 \mathrm{ng} / \mathrm{mL} \text { ) correlated with } \\
\text { APACHE-\|l and SOFA scores }\end{array}$ \\
\hline $\begin{array}{l}\text { Jiao et al. } \\
2015 \text { [53] }\end{array}$ & $\begin{array}{l}\text { Prospective } \\
\text { observational } \\
\text { study }\end{array}$ & $\begin{array}{l}\text { Intracranial } \\
\text { hemorrhage } \\
\text { (ICH) }\end{array}$ & $\begin{array}{l}\text { CSF and } \\
\text { serum } \\
\text { ELISA }\end{array}$ & $22(17)$ & $\begin{array}{l}\text { Claudin-5; } \\
\text { occludin; } \\
\text { ZO-1 }\end{array}$ & $\begin{array}{l}\text { Increased claudin-5, occludin, } \\
\text { and ZO- } 1 \text { in the CSF (1302, } \\
10,934 \text { versus } 157,0.5, \\
181 \mathrm{pg} / \mathrm{mL} \text { respectively) but } \\
\text { not in the serum }(89,13, \\
2008 \text { versus } 126,11,2173 \mathrm{pg} / \\
\mathrm{mL} \text { respectively) of ICH } \\
\text { patients compared to } \\
\text { controls. CSF TJ proteins } \\
\text { have higher sensitivity and } \\
\text { specificity in diagnosis of } \\
\mathrm{ICH} \text { than serum proteins }\end{array}$ \\
\hline
\end{tabular}


Table 3 Summary of studies investigating markers of endothelial injury listed in descending chronological order (Continued)

\begin{tabular}{|c|c|c|c|c|c|c|}
\hline Study & Study design & $\begin{array}{l}\text { Disease } \\
\text { process }\end{array}$ & $\begin{array}{l}\text { Method } \\
\text { of TJ } \\
\text { assessment }\end{array}$ & $\begin{array}{l}\text { \# of Pts } \\
\text { (controls) }\end{array}$ & $\begin{array}{l}\text { TJ } \\
\text { proteins } \\
\text { studied }\end{array}$ & Major findings \\
\hline $\begin{array}{l}\text { Wichapoon } \\
\text { et al. } 2014 \\
\text { [62] }\end{array}$ & $\begin{array}{l}\text { Cross- } \\
\text { sectional } \\
\text { study }\end{array}$ & $\begin{array}{l}\text { Plasmodium } \\
\text { falciparum } \\
\text { malaria }\end{array}$ & $\begin{array}{l}\text { Post-mortem } \\
\text { kidney } \\
\text { biopsy; IHC }\end{array}$ & $20(10)$ & ZO-1 & $\begin{array}{l}\text { Decreased ZO-1 expression } \\
\text { associated with acute kidney } \\
\text { injury in malaria patients }\end{array}$ \\
\hline $\begin{array}{l}\text { Klaus et al. } \\
2013 \text { [63] }\end{array}$ & $\begin{array}{l}\text { Prospective } \\
\text { observational } \\
\text { study }\end{array}$ & Sepsis & $\begin{array}{l}\text { Serum } \\
\text { ELISA }\end{array}$ & $25(38)$ & Zonulin & $\begin{array}{l}\text { Increased serum zonulin ( } 3.4 \\
\text { versus } 6.6 \mathrm{ng} / \mathrm{mL} \text { ) levels in } \\
\text { septic patients compared to } \\
\text { control patients }\end{array}$ \\
\hline $\begin{array}{l}\text { Brito et al. } \\
2012 \text { [55] }\end{array}$ & Case report & Kernicterus & $\begin{array}{l}\text { Post- } \\
\text { mortem } \\
\text { brain } \\
\text { biopsy; IHC }\end{array}$ & $1(1)$ & Claudin-5 & $\begin{array}{l}\text { Increased claudin-5 tissue } \\
\text { staining in the kernicteric } \\
\text { patient }\end{array}$ \\
\hline $\begin{array}{l}\text { Kazmierski } \\
\text { et al. } \\
2012[51]\end{array}$ & $\begin{array}{l}\text { Prospective } \\
\text { observational } \\
\text { study }\end{array}$ & $\begin{array}{l}\text { Ischemic } \\
\text { stroke }\end{array}$ & $\begin{array}{l}\text { Serum } \\
\text { ELISA }\end{array}$ & $458(0)$ & $\begin{array}{l}\text { Claudin-5; } \\
\text { occludin; } \\
\text { ZO-1 }\end{array}$ & $\begin{array}{l}\text { Increased serum occludin } \\
(0 \text { to } 0.08 \mathrm{pg} / \mathrm{mL} \text { ) and claudin- } \\
5 / Z \mathrm{O}-1 \mathrm{ratio}(0 \text { to } 1.47 \text { and } 0.57 \\
\text { to } 1.48 \mathrm{RU} / \mathrm{mL} \text { respectively) is } \\
\text { associated with hemorrhagic } \\
\text { conversion and correlates } \\
\text { with markers of neuron } \\
\text { injury (S100B) }\end{array}$ \\
\hline $\begin{array}{l}\text { Haarmann } \\
\text { et al. } \\
2010 \text { [52] }\end{array}$ & $\begin{array}{l}\text { Prospective } \\
\text { observational } \\
\text { study }\end{array}$ & $\begin{array}{l}\text { Ischemic } \\
\text { stroke and } \\
\text { multiple } \\
\text { sclerosis }\end{array}$ & $\begin{array}{l}\text { Serum } \\
\text { ELISA }\end{array}$ & $13(45)$ & JAM-A & $\begin{array}{l}\text { No significant change in serum } \\
\text { JAM-A ( } 7 \text { to } 15 \mathrm{ng} / \mathrm{mL} \text { ) level } \\
\text { over time in ischemic stroke }\end{array}$ \\
\hline $\begin{array}{l}\text { Brown et al. } \\
1999[64]\end{array}$ & $\begin{array}{l}\text { Prospective } \\
\text { observational } \\
\text { study }\end{array}$ & $\begin{array}{l}\text { Cerebral } \\
\text { malaria }\end{array}$ & $\begin{array}{l}\text { Post- } \\
\text { mortem } \\
\text { brain } \\
\text { biopsy; IHC }\end{array}$ & $14(10)$ & $\begin{array}{l}\text { Occludin; } \\
\text { vinculin; } \\
\text { ZO-1 }\end{array}$ & $\begin{array}{l}\text { Decreased tissue staining of } \\
\text { ZO- } 1 \text {, occludin, and vinculin }\end{array}$ \\
\hline $\begin{array}{l}\text { Castejon OJ } \\
1980[54]\end{array}$ & $\begin{array}{l}\text { Cross- } \\
\text { sectional } \\
\text { study }\end{array}$ & $\begin{array}{l}\text { Cerebral } \\
\text { edema in } \\
\text { trauma, } \\
\text { tumor or } \\
\text { malformation }\end{array}$ & $\begin{array}{l}\text { Brain } \\
\text { biopsy; EM }\end{array}$ & $17(0)$ & Zonulin & $\begin{array}{l}\text { Endothelial junctional } \\
\text { morphology is altered in } \\
\text { moderate and severe cerebral } \\
\text { edema }\end{array}$ \\
\hline
\end{tabular}

CSF cerebral spinal fluid, ELISA enzyme-linked immunosorbent assay, EM electron microscopy, IHC immunohistochemistry, $J A M$ junctional adhesion molecule, MODS multiple organ dysfunction syndrome, $R T-P C R$ reverse transcription polymerase chain reaction, $Z O$ zonula occludens, $N R$ not reported

Notably, no studies investigated multiple organ failure using organ-specific TJ biomarkers in critically ill humans. Furthermore, no studies investigated endothelial TJ structure or function in the context of primary cardiopulmonary disease or failure.

\section{Discussion}

The maintenance of functional tissue barriers is essential to life and the principal functional components of these barriers are TJs. There is great complexity in TJ structure, amplified by their heterogeneity across tissues types (Fig. 1). To best assess these complex, dynamic processes, and determine their utility as potential biomarkers, we combined the limited histologic and biomarker studies available. Our review identifies growing evidence that TJs are disrupted in critical illness and markers of their breakdown do correlate to clinically significant outcomes across multiple disease states, in clinically relevant time points. However, many questions remain as the overall number of identified studies is small and they are of variable quality.

The epithelium comprises a diverse set of tissue barriers, separating air, stool, urine, and all the elements from the interstitium. This functional complexity is reflected in 
tissue-specific molecular composition (Table 1). Studies involving epithelial damage described acute injury to GI tract, and over half of those studies investigated tissue samples. These studies reveal that TJ proteins are downregulated in critical illness, weakening the GI barrier. However, broader interpretation of these results is limited by the heterogeneous techniques employed, variable timing of $\mathrm{TJ}$ assessment with respect to disease presentation and overlapping patterns of protein expression.

Results of epithelial TJ markers from urine and blood, however, are more promising and the collected studies indicate useful clinical applications. These results consistently indicate that serum or urine levels of claudins-2, 3, and 4 correlate with acute GI injury. Although these species are expressed in other tissues, in the clinical context of GI injury, they may prove to be valuable biomarkers. Urinary claudins were an early and reliable measure of GI damage and permeability across several disease processes from NEC to post-surgical GI insults, and could provide clinicians with minimally invasive assessments of gut integrity in real time. Plasma zonulin levels may also be useful in diagnosis of NEC, although they are more significantly elevated in other GI pathologies such as gastroschisis. However, as many of these proteins are also expressed in the kidney and lungs, more research is needed to refine them as tools of tissue-specific injury.

Multiple studies investigated levels of ZO-1, occludin, or zonulin, without concurrent investigation other, more specific of markers of TJs. The aforementioned proteins are expressed in many cells types, potentially confounding their interpretation. Elevation of these proteins in critical illness may reflect a combination of endothelial, epithelial, or organ parenchymal damage. Similar to study of the epithelium, these investigations were a mix of histological examination and measurement of serum protein levels. The six histologic studies identified focused on the vasculature and all found disruption of these proteins during diverse disease states, reinforcing the view that a variety of etiologies of critical ill may converge on a common pathway to disrupt the endothelial barrier. This begs more focused and nuanced research.

Critical illness may induce endothelial TJ disruption through mechanical, ischemic, or overwhelming inflammatory insults. Studies have investigated serum levels of claudin-5, ZO-1, occludin, and zonulin in each setting. In mechanical injury, such as polytrauma and trauma-induced hemorrhagic shock, levels of claudin-5 and JAM-A are elevated and correlate with outcomes. The prognostic value of serum claudin- 5 in hemorrhage conversion of ischemic stroke highlights its utility as a marker of endothelial barrier breakdown following mechanical and ischemic damage. Inflammatory stimulation may lead to the active disassembly of endothelial TJs, as is presumed to occur in capillary leak associated with septic shock. Serum ZO-1, occludin, and zonulin are all elevated in sepsis; however, ZO-1 best stratified sepsis severity and degree of organ dysfunction. That ZO-1 outperformed other TJ markers may reflect the concomitant organ epithelial injury which occurs in multiple organ dysfunction syndrome. Similarly, in Dengue fever, serum levels correlated with the amount of plasma leakage, demonstrating its specificity as a biomarker of vascular barrier dysfunction.

A number of clinical factors may initiate destabilization of epithelial and endothelial barriers in critical illness, such as overwhelming or unrelenting stimulation from inflammatory (i.e., cytokines), hypoxic-ischemic or traumatic insults (i.e., damage-associated molecular patterns). Yet, regardless of the particular instigating factors, injured endothelial and epithelial TJs may share a common molecular pathway of active 
disassembly $[4,65]$. Despite an increasingly thorough understanding of the molecular mechanisms of active TJ breakdown in cell culture [10], very few therapies developed in vitro have shown a translatable clinical impactful. These deficiencies are most notable in sepsis, a hallmark of which is endothelial dysfunction leading to capillary leak [66]. Many anti-cytokine therapies, such as antibodies that target vascular endothelial growth factor or neutralize lipopolysaccharide signaling, have not shown clinical benefit, likely due to complex, time-dependent, and overlapping pathways. Recent trials involving agents that may tighten vascular barriers, such as those that modulate vasopressin $[67,68]$ and adrenomedullin pathways $[69,70]$, are more promising. It is possible that these therapies may counter-act the systemic signaling that leads to TJ disruption in endothelium and epithelium, although additional translational research is required.

To date, there has been minimal investigation on the use of $\mathrm{TJ}$ markers in cardiac or pulmonary failure, a glaring lapse given its high prevalence and the associated morbidity and mortality. Given the prevalence, morbidity, and mortality of cardiopulmonary disease, efforts to identify specific tissue markers or more rigorously exploiting those already known could lead to clinically useful tools. The histologic (IHC and EM) and molecular (ELISA, WB, and RT-PCR) tests utilized in these studies are not clinically available; however, they are available in reliable kits or arranged in coordination with pathology departments. Availability of such tools may provide opportunities for clinicians, with ready access to patient samples, to conduct clinical research on the utility of TJ-derived markers in challenging clinical scenarios. Unfortunately, there is no data comparing different analytical methods (e.g., investigating claudin-3 in urine with a WB or ELISA), to guide researchers, nor have many of these tests been validated in the clinical setting. Identifying the optimal detection methods for TJ proteins, and adapting such tests to the appropriate clinical specimens, present opportunities to advance this line of research. Ultimately, markers of TJ disruption may have the potential to provide clinicians with more precise information to assist in the diagnosis, management, and improved pathophysiologic understanding of diseases such as capillary leak, pulmonary edema, and multiple organ dysfunction syndrome.

There are limitations to this investigation. As we have noted, multiple proteins (e.g., ZO-1, zonulin, occludin, and others) are expressed in endothelial, epithelial, as well as other types of cells. Accordingly, the origin of cellular injury must be interpreted within the various clinical scenarios, which presents challenges in assessing individual studies and as well as comparing results between them. Nonetheless, due in part to a paucity of qualifying studies, we combined multiple pathologies across age ranges, from infants with NEC to adults with SAP all while being cognizant of the multiple factors of timing and technique that could affect the results. In spite of the challenges, we felt it was important to try to understand the range of clinical settings in which TJ-derived biomarkers might be informative. Unfortunately, because of the great variability in methods of assessment, disease state, and results reporting, we are unable to conduct a quantitative meta-analysis. In many cases, interpretation of pathology specimens was qualitative and primary data could not be completely reviewed. The timing of histologic sampling was inconsistently related to disease onset. In addition, we did not consider functional MRI studies of blood-brain barrier function, gut functional permeability studies, trans-pulmonary water or glycocalyx marker studies due to their lack of direct 
assessment of TJ structure and function or TJ-derived proteins. Our review may further be limited by the potential impact of publication bias, as studies not finding a correlation between $\mathrm{TJ}$ disruption and critical illness would be less likely to be published. Although we attempted to identify all relevant studies, it is possible that qualifying studies were inadvertently omitted from this systematic review.

\title{
Conclusions
}

Tight junctions are essential to the integrity of epithelial and endothelial barriers and are often disrupted in critical illness. Accordingly, their protein components may make reliable biomarkers of specific tissue injury. We reviewed 30 heterogeneous studies of TJ structure in critically ill humans which assessed tissue specimens, serum, and urine for levels of TJ-derived proteins. These studies collectively indicated that both epithelial and endothelial barriers are dramatically altered by critical illness. Moreover, initial urine and serum study of tissue-specific proteins have shown potential as powerful diagnostic tools. More investigation, along with standardization of research methods, is required to identify with greater precision the optimal markers of tissue-specific injury and correlate these markers to clinically meaningful outcomes.

\section{Additional files}

Additional file 1: Table S1. Protocol for systematic review. This protocol was derived by group consensus prior to initiation of the systematic review. This protocol is registered in the PROSPERO database of systematic reviews (https://www.crd.york.ac.uk/prospero/display_record.php?RecordID=74546). (DOCX 17 kb)

Additional file 2: Table S2. Medline (PubMed) search strategy. (DOCX $17 \mathrm{~kb}$ )

Additional file 3: Table S3. Embase (Ovid) search strategy. (DOCX $20 \mathrm{~kb}$ )

\section{Abbreviations}

CKD: Chronic kidney disease; CPB: Cardiopulmonary bypass; CSF: Cerebral spinal fluid; ECC: Extracorporeal circulation; ELISA: Enzyme-linked immunosorbent assay; EM: Electron microscopy; EM: Electron microscopy; Gl: Gastrointestinal; HD: Hemodialysis; IF: Immunofluorescence; IHC: Immunohistochemistry; IP: Intestinal permeability; JAM: Junctional adhesion molecule; MODS: Multiple organ dysfunction syndrome; NEC: Necrotizing enterocolitis; NR: Not reported; RTPCR: Reverse transcription polymerase chain reaction; SAP: Severe acute pancreatitis; TJ: Tight junction; WB: Western blot; ZO: Zonula occludens

\section{Acknowledgements}

We would like to thank Professor Maria Balda, University College of London, for her careful review of this manuscript as well as the Yale School of Medicine, Department of Pediatrics and the Cushing/Whitney Medical Library staff for their ongoing support.

\section{Funding}

This work is supported by department funds in the Department of Pediatrics at Yale University.

\section{Availability of data and materials}

Not applicable to this article as no datasets were generated or analyzed during the current study.

\begin{abstract}
Authors' contributions
DV and PH performed the abstract screening, full text review, and data extrapolation, as well as helped to draft the manuscript. MF and JG participated in design of study, search strategies, and review of manuscript. MC participated in design of study and review of manuscript. RP conceived of the study, participated in its design and coordination, mediated consensus meetings for data selection discrepancies, and helped to draft the manuscript. All authors read and approved the final manuscript.
\end{abstract}

Ethics approval and consent to participate

Not applicable.

Consent for publication

Not applicable. 


\section{Publisher's Note}

Springer Nature remains neutral with regard to jurisdictional claims in published maps and institutional affiliations.

\section{Author details}

'Department of Pediatrics, Yale University, 333 Cedar Street, PO Box 208064, New Haven, CT 06520, USA. Cushing/ Whitney Medical Library, Yale University, 333 Cedar Street, PO Box 208064, New Haven, CT 06520, USA.

Received: 2 July 2018 Accepted: 20 September 2018

Published online: 26 September 2018

\section{References}

1. Zihni C, Mills C, Matter K, Balda MS (2016) Tight junctions: from simple barriers to multifunctional molecular gates. Nat Rev Mol Cell Biol 17:564-580

2. Tokes A-M, Schaff Z, Szasz AM, Kulka J (2013) The distribution of tight junctions and junctional proteins in the human bodytight junctions in cancer metastasis, pp 29-64

3. Anderson JM, Van Itallie CM (2009) Physiology and function of the tight junction. Cold Spring Harb Perspect Biol 1:a002584

4. Rahimi N (2017) Defenders and challengers of endothelial barrier function. Front Immunol 8:1847

5. Fishel RS, Are C, Barbul A (2003) Vessel injury and capillary leak. Crit Care Med 31:S502-S511

6. Tatara T (2016) Context-sensitive fluid therapy in critical illness. J Intensive Care 4:20

7. Faustino E, Luckett P, Pierce R (2017) A survey of pediatric critical care providers on the presence, severity, and assessment of capillary leak in critically ill children. J Pediatr Intensive Care 06(03):145-151

8. Farquhar MG, Pallade GE (1963) Junctional complexes in various epithelia. J Cell Biol 17:375-412

9. Furuse M (2009) Knockout animals and natural mutations as experimental and diagnostic tool for studying tight junction functions in vivo. Biochim Biophys Acta 1788:813-819

10. Matter K, Balda MS (2003) Signalling to and from tight junctions. Nat Rev Mol Cell Biol 2003;4(3):225-36

11. Balda MS, Matter K (2016) Tight junctions as regulators of tissue remodelling. Curr Opin Cell Biol 42:94-101

12. Komarova YA, Kruse K, Mehta D, Malik AB (2017) Protein interactions at endothelial junctions and signaling mechanisms regulating endothelial permeability. Circ Res 120:179-206

13. Raleigh DR, Marchiando AM, Zhang Y, Shen L, Sasaki H, Wang Y, Long M, Turner JR (2010) Tight junctionassociated MARVEL proteins marveld3, tricellulin, and occludin have distinct but overlapping functions. Mol Bio Cell 21:1200-1213

14. Ebnet K, Suzuki A, Ohno S, Vestweber D (2004) Junctional adhesion molecules (JAMs): more molecules with dual functions? J Cell Sci 117:19-29

15. Gunzel D, Yu AS (2013) Claudins and the modulation of tight junction permeability. Physiol Rev 93:525-569

16. Krause G, Winkler L, Mueller SL, Haseloff RF, Piontek J, Blasig IE (2008) Structure and function of claudins. Biochim Biophys Acta 1778:631-645

17. Findley MK, Koval M (2009) Regulation and roles for claudin-family tight junction proteins. IUBMB Life 61:431-437

18. Tornavaca O, Chia M, Dufton N, Almagro LO, Conway DE, Randi AM, Schwartz MA, Matter K, Balda MS (2015) ZO-1 controls endothelial adherens junctions, cell-cell tension, angiogenesis, and barrier formation. J Cell Biol 208:821-838

19. Buckley A, Turner JR (2018) Cell biology of tight junction barrier regulation and mucosal disease. Cold Spring Harb Perspect Biol 10

20. Krug SM, Schulzke JD, Fromm M (2014) Tight junction, selective permeability, and related diseases. Semin Cell Dev Biol 36:166-176

21. Hou J (2014) The kidney tight junction (review). Int J Mol Med 34:1451-1457

22. Brune K, Frank J, Schwingshackl A, Finigan J, Sidhaye VK (2015) Pulmonary epithelial barrier function: some new players and mechanisms. Am J Physiol Lung Cell Mol Physiol 308:L731-L745

23. Koval M (2013) Claudin heterogeneity and control of lung tight junctions. Annu Rev Physiol 75:551-567

24. Balda MS, Fallon MB, CMv I, Anderson JM (1992) Structure, regulation, and pathophysiology of tight junctions in the gastrointestinal tract. Yale J Biol Med 65:725-735

25. Garcia-Hernandez V, Quiros M, Nusrat A (2017) Intestinal epithelial claudins: expression and regulation in homeostasis and inflammation. Ann N Y Acad Sci 1397:66-79

26. Dejana E (2004) Endothelial cell-cell junctions: happy together. Nat Rev Mol Cell Biol 5:261-270

27. Aird WC (2012) Endothelial cell heterogeneity. Cold Spring Harb Perspect Med 2:a006429

28. Mehta D, Malik AB (2006) Signaling mechanisms regulating endothelial permeability. Physiol Rev 86:279-367

29. Abbott NJ, Patabendige AA, Dolman DE, Yusof SR, Begley DJ (2010) Structure and function of the blood-brain barrier. Neurobiol Dis 37:13-25

30. Hotchkiss RS, Schmieg RE Jr, Swanson PE, Freeman BD, Tinsley KW, Cobb JP, Karl IE, Buchman TG (2000) Rapid onset of intestinal epithelial and lymphocyte apoptotic cell death in patients with trauma and shock. Crit Care Med 28:3207-3217

31. Hotchkiss RS, Swanson PE, Freeman BD, Tinsley KW, Cobb JP, Matuschak GM, Buchman TG, Karl IE (1999) Apoptotic cell death in patients with sepsis, shock, and multiple organ dysfunction. Crit Care Med 27:1230-1251

32. Hotchkiss RS, Tinsley KW, Swanson PE, Karl IE (2002) Endothelial cell apoptosis in sepsis. Crit Care Med 30:S225-S228

33. Kawamoto O, Michiue T, Ishikawa T, Maeda H (2014) Immunohistochemistry of connexin43 and zonula occludens-1 in the myocardium as markers of early ischemia in autopsy material. Histol Histopathol 29:767-775

34. Laing JG, Saffitz JE, Steinberg TH, Yamada KA (2007) Diminished zonula occludens-1 expression in the failing human heart. Cardiovasc Pathol 16:159-164

35. Schünemann HJ, Fretheim A, Oxman AD (2006) Improving the use of research evidence in guideline development: 9. Grading evidence and recommendations. Health Research Policy and Systems 4:21-21

36. Amadi B, Besa E, Zyambo K, Kaonga P, Louis-Auguste J, Chandwe K, Tarr PI, Denno DM, Nataro JP, Faubion W, Sailer A, Yeruva S, Brantner T, Murray J, Prendergast AJ, Turner JR, Kelly P (2017) Impaired barrier function and autoantibody generation in malnutrition enteropathy in Zambia. EBioMedicine 22:191-199 
37. Derikx JP, van Waardenburg DA, Thuijls G, Willigers HM, Koenraads M, van Bijnen AA, Heineman E, Poeze M, Ambergen T, van Ooij A, van Rhijn LW, Buurman WA (2008) New insight in loss of gut barrier during major non-abdominal surgery. PLoS One 3:e3954

38. Habes QLM, Linssen V, Nooijen S, Kiers D, Gerretsen J, Pickkers P, Scheffer GJ, Kox M (2017) Markers of intestinal damage and their relation to cytokine levels in cardiac surgery patients. Shock 47:709-714

39. Typpo KV, Larmonier CB, Deschenes J, Redford D, Kiela PR, Ghishan FK (2015) Clinical characteristics associated with postoperative intestinal epithelial barrier dysfunction in children with congenital heart disease. Pediatr Crit Care Med 16:37-44

40. Greis C, Rasuly Z, Janosi RA, Kordelas L, Beelen DW, Liebregts T (2017) Intestinal T lymphocyte homing is associated with gastric emptying and epithelial barrier function in critically ill: a prospective observational study. Crit Care 21:70

41. Sipola S, Ala-Kokko TI, Laurila JJ, Saarnio J, Ohtonen P, Syrjala H, Karttunen TJ (2017) Colon epithelial injury in criticall ill colectomized patients: aberration of tight junction proteins and toll-like receptors. Minerva Anestesiol 83:1017-1025

42. Liew VY, Chapman MJ, Nguyen NQ, Cousins CE, Plummer MP, Chapple LA, Abdelhamid YA, Manton ND, Swalling A, Sutton-Smith P, Burt AD, Deane AM (2016) A prospective observational study of the effect of critical illness on ultrastructural and microscopic morphology of duodenal mucosa. Crit care resuscit j Aust Acad Crit Care Med 18:102-108

43. Blackwood BP, Wood DR, Yuan CY, Nicolas JD, Griffiths A, Mestan K, Hunter CJ (2015) Urinary claudin-2 measurements as a predictor of necrotizing enterocolitis: a pilot study. J Neonatal Surg 4(4):43.eCollection

44. Thuijls G, Derikx JP, van Wijck K, Zimmermann L, Degraeuwe PL, Mulder TL, Van der Zee DC, Brouwers HA, Verhoeven BH, van Heurn LW, Kramer BW, Buurman WA, Heineman E (2010) Non-invasive markers for early diagnosis and determination of the severity of necrotizing enterocolitis. Ann Surg 251:1174-1180

45. Tarko A, Suchojad A, Michalec M, Majcherczyk M, Brzozowska A, Maruniak-Chudek I (2017) Zonulin: a potential marker of intestine injury in newborns. Dis Markers 2017:2413437

46. Plaen IGD, Chou PM, Weber CR (2012) Claudin 2 protein expression is increased in human necrotizing enterocolitis. The FASEB Journal 26: Sup 1162:1161

47. Wen W, Zheng H, Jiang Y, Huang L, Li D, Zhang J, Zhang D (2017) Effect of intestinal epithelial autophagy on bacterial translocation in severe acute pancreatitis. Clin Res Hepatol Gastroenterol 41:703-710

48. Sonika U, Goswami P, Thakur B, Yadav R, Das P, Ahuja V, Saraya A (2017) Mechanism of increased intestinal permeability in acute pancreatitis: alteration in tight junction proteins. J Clin Gastroenterol 51(5):461-466

49. Deng WS, Zhang J, Ju H, Zheng HM, Wang J, Wang S, Zhang DL (2015) Arpin contributes to bacterial translocation and development of severe acute pancreatitis. World J Gastroenterol 21:4293-4301

50. Ji B, Zhou F, Han L, Yang J, Fan H, Li S, Li J, Zhang X, Wang X, Chen X, Xu Y (2017) Sodium Tanshinone IIA sulfonate enhances effectiveness Rt-PA treatment in acute ischemic stroke patients associated with ameliorating blood-brain barrier damage. Transl Stroke Res 8:334-340

51. Kazmierski R, Michalak S, Wencel-Warot A, Nowinski WL (2012) Serum tight-junction proteins predict hemorrhagic transformation in ischemic stroke patients. Neurology 79:1677-1685

52. Haarmann A, Deiss A, Prochaska J, Foerch C, Weksler B, Romero I, Couraud PO, Stoll G, Rieckmann P, Buttmann M (2010) Evaluation of soluble junctional adhesion molecule-A as a biomarker of human brain endothelial barrier breakdown. PLoS One 5:e13568

53. Jiao X, He P, Li Y, Fan Z, Si M, Xie Q, Chang X, Huang D (2015) The role of circulating tight junction proteins in evaluating blood brain barrier disruption following intracranial hemorrhage. Dis Markers 2015:860120

54. Castejon OJ (1980) Electron microscopic study of capillary wall in human cerebral edema. J Neuropathol Exp Neurol 39: 286-328

55. Brito MA, Zurolo E, Pereira P, Barroso C, Aronica E, Brites D (2012) Cerebellar axon/myelin loss, angiogenic sprouting, and neuronal increase of vascular endothelial growth factor in a preterm infant with kernicterus. J Child Neurol 27:615-624

56. Du Y, Xu JT, Jin HN, Zhao R, Zhao D, Du SH, Xue Y, Xie XL, Wang Q (2017) Increased cerebral expressions of MMPs, CLDN5, OCLN, ZO1 and AQPs are associated with brain edema following fatal heat stroke. Sci Rep 7:1691

57. Halbgebauer R, Braun CK, Denk S, Mayer B, Cinelli P, Radermacher P, Wanner GA, Simmen HP, Gebhard F, Rittirsch D, Huber-Lang M (2017) Hemorrhagic shock drives glycocalyx, barrier and organ dysfunction early after polytrauma. J Crit Care 44:229-237

58. Denk S, Wiegner R, Hones FM, Messerer DA, Radermacher P, Weiss M, Kalbitz M, Ehrnthaller C, Braumuller S, McCook O, Gebhard F, Weckbach S, Huber-Lang M (2015) Early detection of junctional adhesion molecule-1 (JAM-1) in the circulation after experimental and clinical polytrauma. Mediat Inflamm 2015:463950

59. Aslan A, van Meurs M, Moser J, Popa ER, Jongman RM, Zwiers PJ, Molema G, Zijlstra JG (2017) Organ-specific differences in endothelial permeability-regulating molecular responses in mouse and human Sepsis. Shock 48:69-77

60. Suwarto S, Sasmono RT, Sinto R, Ibrahim E, Suryamin M (2017) Association of endothelial glycocalyx and tight and adherens junctions with severity of plasma leakage in dengue infection. J Infect Dis 215:992-999

61. Zhao GJ, Li D, Zhao Q, Lian J, Hu TT, Hong GL, Yao YM, Lu ZQ (2016) Prognostic value of plasma tight-junction proteins for sepsis in emergency department: an observational study. Shock 45:326-332

62. Wichapoon B, Punsawad C, Chaisri U, Viriyavejakul P (2014) Glomerular changes and alterations of zonula occludens-1 in the kidneys of plasmodium falciparum malaria patients. Malar J 13:176

63. Klaus DA, Motal MC, Burger-Klepp U, Marschalek C, Schmidt EM, Lebherz-Eichinger D, Krenn CG, Roth GA (2013) Increased plasma zonulin in patients with sepsis. Biochem Med (Zagreb). 23(1):107-11

64. Brown H, Hien TT, Day N, Mai NTH, Chuong LV, Chau TTH, Loc PP, Phu NH, Bethell D, Farrar J, Gatter K, White N, Turner G (1999) Evidence of blood-brain barrier dysfunction in human cerebral malaria. Neuropathol Appl Neurobiol 25:331-340

65. Förster C (2008) Tight junctions and the modulation of barrier function in disease. Histochem Cell Biol 130:55-70

66. Opal SM, van der Poll T (2015) Endothelial barrier dysfunction in septic shock. J Intern Med 277(3):277-293

67. Russell JA, Vincent J-L, Kjølbye AL, Olsson H, Blemings A, Spapen H, Carl P, Laterre P-F, Grundemar L (2017) Selepressin, a novel selective vasopressin $\mathrm{V}(1 \mathrm{~A})$ agonist, is an effective substitute for norepinephrine in a phase lla randomized, placebo-controlled trial in septic shock patients. Crit Care 21:213 
68. Selepressin Evaluation Programme for Sepsis-Induced Shock - Adaptive Clinical Trial (SEPSIS-ACT). https://clinicaltrials. gov/ct2/show/NCT02508649

69. Geven C, Kox M, Pickkers P (2018) Adrenomedullin and adrenomedullin-targeted therapy as treatment strategies relevant for sepsis. Frontiers in Immunology 9

70. Treatment of Patients With Early Septic Shock and Bio-Adrenomedullin(ADM) Concentration $>70 \mathrm{pg} / \mathrm{ml}$ With ADRECIZUMAB (AdrenOSS-2). https://clinicaltrials.gov/ct2/show/NCT03085758

71. Bein A, Eventov-Friedman S, Arbell D, Schwartz B (2017) Intestinal tight junctions are severely altered in NEC preterm neonates. Pediatr Neonatol [ePub ahead of print]

72. Goswami P, Sonika U, Khan IA, Nag T, Sreenivas V, Saraya A (2017) Altered expression of tight junction (TJ) proteins and TJ dilation associated with organ failure (OF) in acute pancreatitis. Gastroenterology 152:S490-S491

Submit your manuscript to a SpringerOpen ${ }^{0}$ journal and benefit from:

- Convenient online submission

- Rigorous peer review

- Open access: articles freely available online

High visibility within the field

Retaining the copyright to your article

Submit your next manuscript at $\boldsymbol{\nabla}$ springeropen.com 